Article

\title{
Biopharmaceutical Characterization and Bioavailability Study of a Tetrazole Analog of Clofibric Acid in Rat
}

\author{
Nancy Vara-Gama ${ }^{1}$, Adriana Valladares-Méndez ${ }^{1}$, Gabriel Navarrete-Vazquez ${ }^{1}$, \\ Samuel Estrada-Soto ${ }^{1}$, Luis Manuel. Orozco-Castellanos ${ }^{2, *}$ and Julio César Rivera-Leyva ${ }^{1, *}$ \\ 1 Facultad de Farmacia, Universidad Autónoma del Estado de Morelos, 62209 Cuernavaca, Morelos, Mexico; \\ nvara83@yahoo.com.mx (N.V.-G.); vameadri25@hotmail.com (A.V.-M.); \\ gabriel_navarrete@uaem.mx (G.N.-V.); enoch@uaem.mx (S.E.-S.) \\ 2 Departamento de Farmacia, Universidad de Guanajuato, 36050 Guanajuato, Guanajuato, Mexico \\ * Correspondence: orozcoz@ugto.mx (L.M.O.-C.); julio.rivera@uaem.mx (J.C.R.-L.)
}

Academic Editor: Diego Muñoz-Torrero

Received: 19 December 2016; Accepted: 7 February 2017; Published: 14 February 2017

\begin{abstract}
In the current investigation, the physicochemical, biopharmaceutical and pharmacokinetic characterization of a new clofibric acid analog (Compound 1) was evaluated. Compound 1 showed affinity by lipophilic phase in 1 to $5 \mathrm{pH}$ interval, indicating that this compound would be absorbed favorably in duodenum or jejunum. Also, Compound 1 possess two ionic species, first above of $\mathrm{pH} 4.43$ and, the second one is present over $\mathrm{pH}$ 6.08. The apparent permeability in everted sac rat intestine model was $8.73 \times 10^{-6} \mathrm{~cm} / \mathrm{s}$ in duodenum and $1.62 \times 10^{-5} \mathrm{~cm} / \mathrm{s}$ in jejunum, suggesting that Compound 1 has low permeability. Elimination constant after an oral administration of $50 \mu \mathrm{g} / \mathrm{kg}$ in Wistar rat was $1.81 \mathrm{~h}^{-1}$, absorption constant was $3.05 \mathrm{~h}^{-1}, \mathrm{C}_{\max }$ was $3.57 \mu \mathrm{g} / \mathrm{mL}$ at $0.33 \mathrm{~h}, \mathrm{AUC}_{0-\alpha}$ was $956.54 \mu / \mathrm{mL} \cdot \mathrm{h}$ and distribution volume was $419.4 \mathrm{~mL}$. To IV administration at the same dose, ke was $1.21 \mathrm{~h}^{-1}, \mathrm{Vd}$ was $399.6 \mathrm{~mL}$ and $\mathrm{AUC}_{0-\alpha}$ was $747.81 \mu / \mathrm{mL} \cdot \mathrm{h}$. No significant differences were observed between pharmacokinetic parameters at every administration route. Bioavailability evaluated was $10.4 \%$. Compound 1 is metabolized to Compound 2 probably by enzymatic hydrolysis, and it showed a half-life of $9.24 \mathrm{~h}$. With these properties, Compound 1 would be considered as a prodrug of Compound $\mathbf{2}$ with potential as an antidiabetic and anti dyslipidemic agent.
\end{abstract}

Keywords: diabetes; bioavailability; clofibric acid; $11 \beta-H S D 1$; tetrazole; dyslipidemia

\section{Introduction}

\subsection{Type 2 Diabetes (DMT2)}

DMT2 is a chronic-degenerative disease characterized by a deficiency in the production of insulin by the $\beta$ cells of the pancreas or the inability of the organism to efficiently use of insulin produces [1]. There were 6.4 million adults over the age of 20 diagnosed with diabetes in 2012 (National Health and Nutrition Survey) [2]. Due to this growing epidemiological trend, Diabetes Mellitus (DM) is considered a very significant public health problem in this country and around the world, and is one of the primary causes of death in the Mexican population.

The complications associated with DMT2 include damage to the capillaries of the kidney, (causing glomerulonephritis and renal failure in its advanced stages), damage to the capillaries of the retina (causing blindness), peripheral neuropathy, myocardial infarction, cerebrovascular complications, and arteriosclerosis [3-6]. Some cases present dyslipidemia, a condition caused by alterations to the concentrations of lipoproteins in the blood. Overweight, obesity, physical inactivity, smoking, and alcohol consumption contribute to the development of this condition [6,7]. Treatments 
for dyslipidemia include inhibitors of the enzyme 3-hydroxy-3-methyl-glutaryl-coenzyme A reductase (statins), inhibitors of the absorption of cholesterol (ezetimibe), fatty acids such as omega-3, and fibric acid derivatives (bezafibrate, clofibrate and fenofibrate). Fibrates are prodrugs metabolized via enzymatic hydrolysis into active metabolites in the form of carboxylic acids. Clofibrate is metabolized (A) into clofibric acid (B, active metabolite) and is the drug of choice for the treatment of dyslipidemias associated with DMT2 [7,8]. Figure 1 shows the structure of the compounds described above.

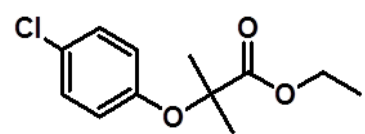

A

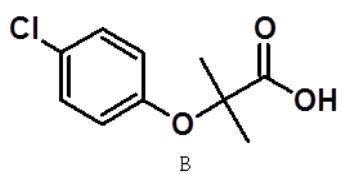

Figure 1. Chemical structure of clofibrate (A) and clofibric acid (B).

\subsection{Pharmacological Activity of Fibrates}

Clofibric acid is an agonist of nuclear receptors activated by peroxisome proliferator-activated receptor alpha (PPAR- $\alpha$ ), whose function is related to processes that regulate the metabolism of fats, such as $\beta$-oxidation and adipogenesis $[9,10]$. PPAR- $\alpha$ s are significant therapeutic targets for the treatment of dyslipidemia. Fenofibrate has been reported to act as an anti dyslipidemic and has an inhibitory effect against the $11 \beta$-hydroxysteroid dehydrogenase type 1 (11ß-HSD1), an enzyme expressed principally in muscle, liver and adipose tissue, which catalyzes the conversion of the inactive hormone cortisone to cortisol. This activates hepatic glycogenolysis, enabling glycogen to release glucose, thus further increasing glucose concentrations in the central circulatory system [11]. This enzyme is involved in the complications associated with DT2 [12,13].

Previous studies have shown that Saroglitazar (the PPAR $\alpha / \gamma$ dual agonist used for the treatment of DMT2 and dyslipidemia) produces a significant reduction in lipids and glucose in DT2 patients [14], while Chiglitazar (a PPAR $\alpha / \gamma$ dual agonist) reduces glucose levels and body weight in animals [15]. It is very possible that fibrates are able induce a double therapeutic effect, such as the abovementioned compounds, and control over both blood lipoproteins and hyperglycemia by inhibiting the hepatic glycogenolysis pathway activated by cortisol. The new compound 2-(4-chlorophenoxy)-2-methyl- $N$-(1H-tetrazol-5-yl) propanamide (Figure 2), a tetrazole isosteric analog of clofibric acid (Compound 1), is an aza-heterocyclic amide derived from clofibric acid, to which a tetrazole ring ( $\log \mathrm{D}$ of -0.37 and $\mathrm{p} K_{\mathrm{a}} 4.9$ ) was added as a surrogate of carboxylic acid (Log D of -1.65 and $\mathrm{p} K_{\mathrm{a}}$ 4.76) [16]. The inhibitory effect of Compound 1 against the enzyme 11 $\beta$-hydroxysteroid dehydrogenase type 1 (11ß-HSD1) on the cellular line HEK293 (human embryonic kidney cells) was evaluated in vitro, demonstrating a moderate effect against the enzyme $(51.17 \%$ inhibition at $10 \mu \mathrm{M})$ and a higher inhibition than clofibrate and clofibric acid $[17,18]$. The anti-diabetic effect of Compound 1 was determined at $50 \mathrm{mg} / \mathrm{kg}$ single dose using a non-insulin dependent diabetes mellitus rat model. The results indicated a significant reduction in glucose levels in the plasma, up to $77 \%$ $7 \mathrm{~h}$ post-administration, at which point it was compared with glibenclamide, which only reduced the glucose levels by $40 \%$ [18,19].

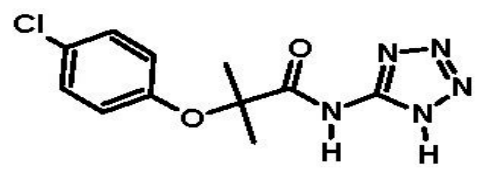

Figure 2. Chemical structure of 2-(4-chlorophenoxy)-2-methyl- $N$-(1H-tetrazol-5-yl) propanamide (tetrazole analog of clofibric acid) (Compound 1).

Given the potential of Compound 1 for the treatment of DMT2 and dyslipidemia, this study proposes the evaluation of its bioavailability in a rat model, as well as its biopharmaceutical characterization. 


\section{Materials and Methods}

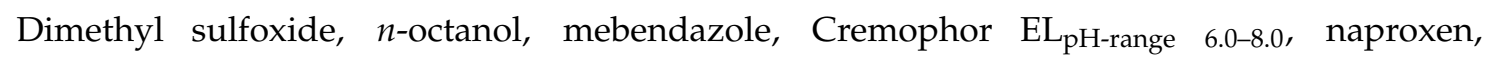
and amoxicillin were purchased from Sigma Aldrich (Steinheim, Germany). Methanol, acetonitrile, and water were HPLC grade, and the sodium hydroxide, phenolphthalein, monobasic sodium phosphate, phosphoric acid, and potassium biphthalate were obtained from J.T. Baker (J.T. Baker, Co., Center Valley, PA, USA). Clofibric acid (Compound 2) was purchased from Sigma Aldrich (Steinheim, Germany). Compound $\mathbf{1}$ was synthesized in the Medicinal Chemistry Laboratory of the Pharmacy Faculty, Autonomous University of the State of Morelos (Universidad Autónoma del Estado de Morelos, or UAEM), Mexico.

\subsection{Physicochemical Evaluations}

\subsection{1. $\mathrm{p} K_{\mathrm{a}}$ Determination via Potentiometric Analysis}

The determination of $\mathrm{p} K_{\mathrm{a}}$ was undertaken as described by Babic A. et al. [18,20]. Compound 1 was prepared by weighing 0.001 equivalents, which were dissolved in the minimum volume of methanol, to which aqueous solution with an ionic strength of $0.02 \mathrm{M}$ was added to obtain a final concentration for Compound 1 of $0.006 \mathrm{M}$. It was titrated with $\mathrm{NaOH} 0.01 \mathrm{~N}$, which had been previously evaluated with an ionic strength of 0.02 M using Logger Pro 3.5.0 software (Vernier Software \& Technology, Beaverton, OR, USA). The study was conducted in triplicate, determining the final points using the criteria from the first and second derivative test [21].

\subsubsection{Apparent Partition Coefficient}

The octanol-water distribution coefficient was determined using the shake-flask method. The two phases were mutually saturated by shaking for $15 \mathrm{~min}$. Phosphate buffers were used as the aqueous phase for the $\mathrm{pH}$ range 1.2 to $13.5 \mathrm{~mL}$ portions of different buffer solutions ( $\mathrm{pH} 1.2$ to 13) containing $100 \mathrm{\mu g} / \mathrm{mL}$ of Compound 1 were mixed with $2.5 \mathrm{~mL}$ of $n$-Octanol. The mixture was shaken for $30 \mathrm{~min}$, centrifuged at $8000 \times \mathrm{g}$ for $10 \mathrm{~min}$, after which the aqueous and organic phases were separated. Aqueous samples were analyzed at $222 \mathrm{~nm}$ using a validated spectrophotometric method (5-200 $\left.\mu \mathrm{g} \cdot \mathrm{mL}^{-1}\right)$ [22-24]. The distribution coefficient (log D) was calculated according to Equation (1) for each $\mathrm{pH}$ value:

$$
\log D=\log \frac{[\text { Compound }] \text { org }}{[\text { Compound }] a q}
$$

where [Compound $]_{\text {org }}$ is the drug concentration in the organic phase (determined by mass balance) and [Compound $]_{a q}$ is the drug concentration in the aqueous phase for each buffer solution. Every experiment was evaluated in triplicate.

\subsubsection{Permeability Assay}

Male Wistar rats weighing 200-250 g were used in this research. Everted intestinal sacs were prepared by quickly removing the small intestine from starved rats killed under ether anesthesia. All experiments were carried out after pre-incubation at $37 \pm 0.5^{\circ} \mathrm{C}$, with the duodenum and jejunum then excised, flushed-through several times with saline solution at room temperature, and placed immediately into simulated intestinal fluid (SIF). The intestine was gently everted over a steel rod and filled with fresh SIF. The sacs were preincubated in oxygenated buffer solution for 5 min and then placed in $100 \mathrm{~mL}$ of oxygenated SIF solution containing $0.0001 \mathrm{M}(100 \mu \mathrm{M})$ of Compound $\mathbf{1}$ at $37^{\circ} \mathrm{C}$. Oxygen was bubbled with a pump to maintain viable tissue [25].

The everted intestinal sac was filled with $1.5 \mathrm{~mL}$ of SIF solution, while a test compound solution $(0.0001 \mathrm{M})$ remained external to the everted sac. The high and low permeability markers, naproxen and amoxicillin, were prepared in the same way [26]. $300 \mu \mathrm{L}$ samples were collected from inside the sac with a metallic cannula at 5, 10, 15, 30, 45, 60, 90, and 120 min (apical-basolateral transport A-B), 
after which a medium replacement was made. Both an initial and final sample of the outside solution were analyzed by HPLC.

The apparent intestinal permeability $\left(P_{a p p}\right)$ was calculated according to Equation (2):

$$
\text { Papp }=\frac{V}{(A * C o)} d C / d t
$$

where $P_{a p p}=$ Apparent Permeability $(\mathrm{cm} / \mathrm{s}), V=$ Intestinal Volume $(\mathrm{mL}), A=$ Surface Area $\left(\mathrm{cm}^{2}\right)$, $d C / d t=$ Concentration Gradient, and, $C o=$ Initial Concentration $(\mu \mathrm{g} / \mathrm{mL})$.

\subsection{Chromatographic Conditions}

The samples of Compound 1 were analyzed using a Waters chromatographic system equipped with a 717 plus auto-sampler, a model 515 isocratic pump, and a model 2487 UV-Vis detector. The software used was N2000 Chromatostation. The separation was performed on a $4.6 \times 250 \mathrm{~mm}$ Zorbax CN (Agilent technologies, Santa Clara, CA, USA). The mobile phase consisted of phosphate buffer $(0.05 \mathrm{M}, \mathrm{pH} 3.5)$ with $0.06 \%$ ethanol and methanol HPLC grade (64:36), filtered through $0.2 \mu \mathrm{m}$ Nylon membrane (Nylaflo ${ }^{\mathrm{TM}}$ ) from PALL Corporation (Washington, NY, USA) and sonicated for $30 \mathrm{~min}$. The flow rate was $1.0 \mathrm{~mL} / \mathrm{min}$. The column was kept at room temperature. Total run time was $25 \mathrm{~min}$, with the detection carried out at $223 \mathrm{~nm}$. The injection volume was $10 \mu \mathrm{L}$.

\subsubsection{Calibration Curve}

A methanol solution of Compound 1 and clofibric acid (Compound 2) was prepared to a final concentration of $100 \mu \mathrm{g} / \mathrm{mL}$ (working solutions). The calibration curves were prepared using appropriate volumes of Compound 1, Compound 2, and rat plasma to obtain the following concentrations: $0.46,0.93,3.75,7.5,15,30 \mu \mathrm{g} / \mathrm{mL}$ (Compound 1); and, 0.78, 1.56, 6.25, 12.5, 25, and $50 \mu \mathrm{g} / \mathrm{mL}$ (Compound 2), simultaneously. Internal standard (mebendazole) was prepared at a concentration of $20 \mu \mathrm{g} / \mathrm{mL}$ (IS working solution).

\subsubsection{Sample Preparation}

$100 \mu \mathrm{L}$ of plasma containing Compounds $\mathbf{1}$ and $\mathbf{2}$ at different concentrations were transferred to Eppendorf tubes, with $10 \mu \mathrm{L}$ of IS working solution, $100 \mu \mathrm{L} 1 \%$ solution phosphoric acid then added. Samples were shaken in a vortex for $30 \mathrm{~s}$. Strata- $X 33 \mu \mathrm{m}$ cartridges (Polymeric Reversed Phase, $30 \mathrm{mg}$, Phenomenex) were conditioned with $2 \mathrm{~mL}$ of methanol and $1 \mathrm{~mL}$ of water, with the sample in the cartridge then left to stand for $2 \mathrm{~min}$ and immediately washed with $1 \mathrm{~mL}$ of a 95:5 water methanol solution. Finally, the sample was eluted four times with $500 \mu \mathrm{L}$ of a 50:50 methanol acetonitrile solution. Samples were evaporated under atmospheric nitrogen at $40{ }^{\circ} \mathrm{C}$. The waste reconstituted in methanol and $10 \mu \mathrm{L}$ was injected into the HPLC.

\subsection{Analytical Method Validation}

The analytical method was validated in plasma using the following parameters: selectivity, linearity, precision, accuracy, absolute recovery, and LOQ [27].

\subsubsection{Selectivity}

Blank plasma samples from different rat sources were prepared as previously described, to check for signals that might interfere with the detection of the analytes (Compound $\mathbf{1}$ and Compound 2) or the IS. Additionally, the blank sample (a processed matrix sample without analyte and without IS) and a zero sample (a processed matrix with IS) were analyzed.

Also, specificity was demonstrated by comparing samples containing Cremophore EL and Heparine $10 \mathrm{UI} / \mathrm{mL}$. 


\subsubsection{Linearity}

The calibration curve was prepared in triplicate on two different days and the data analyzed as described above. The area ratio of Compound $1 /$ IS peaks (AR) was calculated. The linearity was determined between the $0.46-30 \mu \mathrm{g} / \mathrm{mL}$ recorded for Compound 1 and the $0.78-50 \mu \mathrm{g} / \mathrm{mL}$ recorded for Compound 2, with the linear regression parameters as determined were the confidence intervals for slope and intercept.

\subsubsection{Precision and Accuracy}

Aliquots of blank plasma were spiked with the corresponding volume of Compound 1 working solution and metabolite to obtain quality control (QC) samples containing $1.5 \mu \mathrm{g} / \mathrm{mL}$ (LQC), $18 \mu \mathrm{g} / \mathrm{mL}$ (MQC) and $24 \mu \mathrm{g} / \mathrm{mL}$ (HQC). For precision, the quality control samples were prepared in quintuplicate on two different days. Repeatability and reproducibility were calculated and expressed as RSD\%. The within-run and between-run RSD \% values were not to exceed $15 \%$ for each QC level. For accuracy, the QC samples were analyzed against a freshly calculated calibration curve, with the obtained concentrations compared with the nominal value. The accuracy was reported as a percentage of the nominal value. The mean concentration was to be within $15 \%$ of the nominal values for the QC samples.

\subsubsection{Extraction Efficiency}

The efficiency of the extraction method was determined by comparing the plasma QC samples with aqueous QC solutions at corresponding levels for Compound $\mathbf{1}$ and Compound $\mathbf{2}$ to compare recovery, and measured in triplicate in the same analytical batch. Extraction efficiency was expressed as a percentage of the nominal concentration.

\subsubsection{Limit of Quantification (LOQ) and Limit of Detection (LOD)}

The LOQ for the proposed methods was established through the analysis of the blank samples containing the lowest concentration level on each curve for every compound, determined experimentally by analyzing six replicates with suitable precision and accuracy (RSD $<20 \%$ ).

\section{Bioavailability Study}

\subsection{Animals}

Male Wistar rats weighing 250-300 g were used for pharmacokinetic evaluation. Animals were individually identified by tail markings and acclimated to the study environment for seven days prior to the administration of the dose. Animals were kept on a $12 \mathrm{~h}$ light/dark cycle except when this was interrupted for study procedures. Animals were kept at average room temperature, which was regulated in the range of 18 to $29^{\circ} \mathrm{C}$. The animals were fasted prior to dose administration, and had access to water ad libitum.

\subsection{Cannulation}

Rats were anesthetized with ether and cannulated via the caudal vein using polyethylene tubing with an internal diameter of 0.023 inches, and an outer diameter of 0.038 inches (Becton Dickinson Clay Adams) [28].

\subsection{Administration}

Compound 1 was prepared with Cremophore (10\%) in physiologic saline solution and administered orally in a $50 \mathrm{mg} / \mathrm{kg}$ dose, and via intravenous bolus ( $50 \mathrm{mg} / \mathrm{kg}$ ). Study was conducted in quintuplicate. 


\subsection{Sample Collection}

After dosing, serial blood samples were collected (0.2 mL) 0, 0.083, 0.16, 0.25, 0.33, 0.50, 0.75, 1.0, $1.5,2.0,3.0,4.0,6.0$, and $8 \mathrm{~h}$ after both oral and intravenous administration using heparinized (20 UI) tubes, and were centrifuged at $5000 \times g$ for $10 \mathrm{~min}$, with the plasma harvested and analyzed by HPLC using the previously validated method.

\section{Pharmacokinetic Analysis}

The pharmacokinetic parameters of Compound $\mathbf{1}$ were obtained via non-compartmental analysis $[29,30]$ using PK software (PKSolver). The STATA statistical program, version 12, was used for the comparison of the following: the pharmacokinetic parameters obtained via both administration pathways $\left(C_{\max }\right.$ and $\left.\mathrm{T}_{\max }\right)$; the elimination rate constant $\left(\mathrm{k}_{\mathrm{el}}\right)$; the biological half-life; the area under the curve $\left(\mathrm{AUC}_{0-\mathrm{t}}\right)$; the area under the curve from zero to infinity $\left(\mathrm{AUC}_{0}-\infty\right)$; volume of distribution (Vd); clearance (Cl); and, absolute bioavailability (F).

\section{Bioethics Policies}

This study followed the international recommendations for animal handling in biomedical research outlined in the Principles of Laboratory Animal Care (NIH publication \#85-23, revised in 1985) and the current Mexican Official Standard NOM-062-ZOO-1999 on the management of laboratory animals [31,32].

\section{Results and Discussion}

\subsection{Biopharmaceutical Properties}

Compound 1 has a tetrazole ring and shows a good affinity for the lipophilic phase in the interval of $\mathrm{pH}$ evaluated from 1 to 5 , in which the $\log \mathrm{D}$ values obtained were positive (Figure 3 ). This indicates that Compound 1 could have a greater affinity in physiological intervals of $\mathrm{pH}$ from 1 to 5 in that non-ionized form prevails and is probably able to achieve a good rate of absorption at the stomach and duodenum section. At pH $7 \log \mathrm{D}$, the species with a higher level of ionization predominate, with the value recorded falling to below zero, indicating that Compound $\mathbf{1}$ has a greater affinity for the polar phase and a low affinity for the non-polar phase, reducing the probability of an improved absorption in the jejunum.

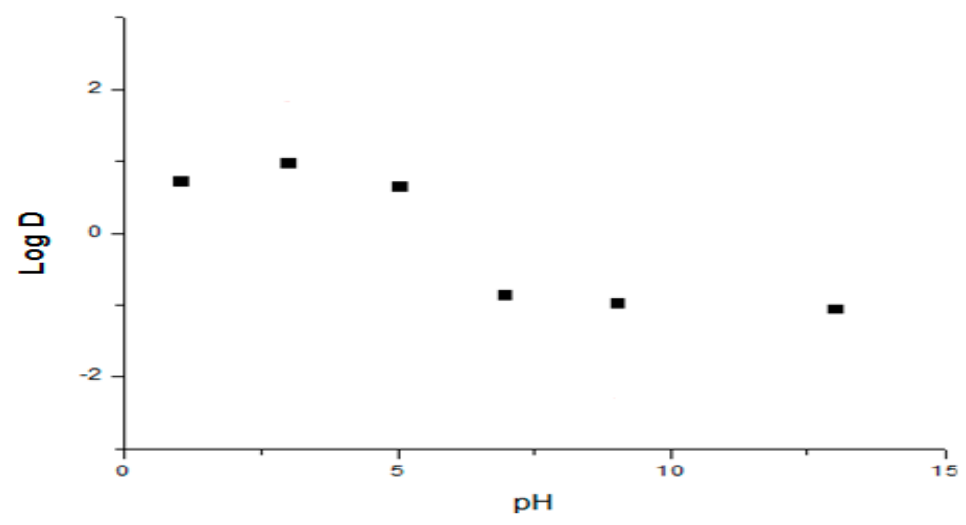

Figure 3. Log D of Compound 1 dependent on $\mathrm{pH}$.

The $\mathrm{p} K_{\mathrm{a}}$ values obtained (Table 1) suggest that the neutral form of the molecule of Compound $\mathbf{1}$ is found in the interval between $\mathrm{pH} 1$ and 5, before the appearance of the first $\mathrm{p} K_{\mathrm{a}}$ value, as observed in Figure 4. 
Table 1. $\mathrm{p} K_{\mathrm{a}}$ observed for Compound 1.

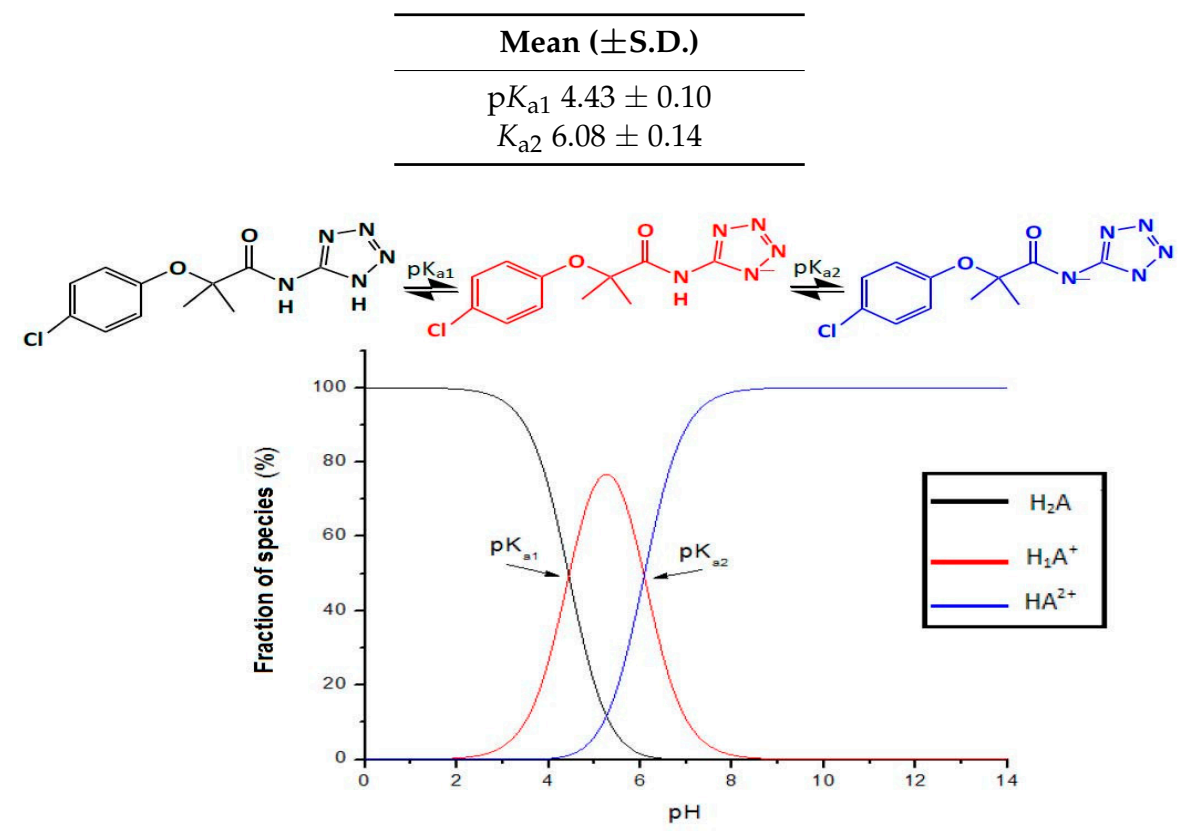

Figure 4. Dissociation equilibrium and speciation diagram for Compound $\mathbf{1 .}$

As Figure 4 shows, the $\mathrm{pH}$ in the gastrointestinal tract at intervals from 1 to 8 , Compound 1 could be non-ionized. Thus at a $\mathrm{pH}$ below 4 , it could be capable of easily passing through the biological membranes via passive transport (transcellular transport). The dissociation equilibrium shows two ionized species of Compound $\mathbf{1}$ in the interval of physiological $\mathrm{pH}$.

The evaluation of apparent permeability $\left(P_{a p p}\right)$ in the rat everted rat gut model (Figure 5), shows that Compound $\mathbf{1}$ has a coefficient of permeability similar to amoxicillin (the standard for low permeability used here) in both the duodenum and the jejunum. The values corresponding to the permeability of Compound 1 and the standards for high and low permeability are presented in Table 2 . The permeability of Compound $\mathbf{1}$ is higher in the jejunum compared to the duodenum, with the standards of permeability showing the same behavior. However, Compound $\mathbf{1}$ shows a slightly higher level of permeability than the standard of low permeability (amoxicillin), thus possibly demonstrating better absorption than amoxicillin.

A

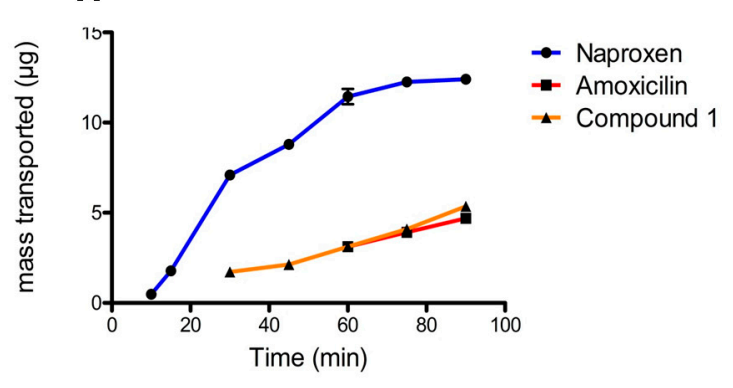

Duodenum

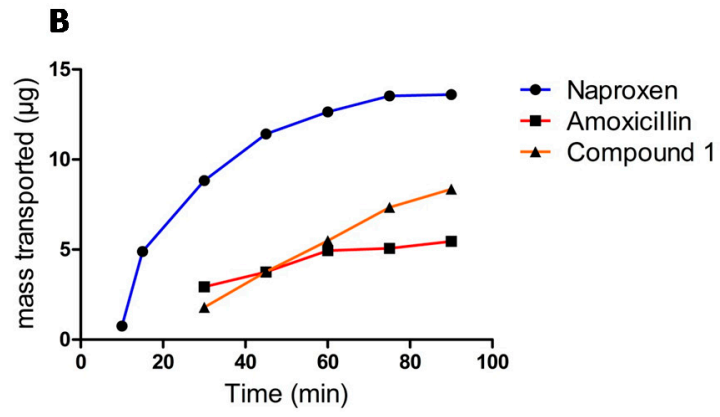

Jejunum

Figure 5. Permeability of Compound $\mathbf{1}$ in the everted rat gut model in the duodenum (A) and jejunum (B). 
Table 2. Permeability of Compound $\mathbf{1}$ in the everted rat gut model.

\begin{tabular}{ccc}
\hline Compound & \multicolumn{2}{c}{$P_{\text {app }}(\mathrm{cm} / \mathbf{s})$} \\
\hline & Duodenum & Jejunum \\
\hline Naproxen & $3.02 \times 10^{-5}$ & $3.98 \times 10^{-5}$ \\
Amoxicillin & $8.52 \times 10^{-6}$ & $1.00 \times 10^{-5}$ \\
ATAC & $8.73 \times 10^{-6}$ & $1.62 \times 10^{-5}$ \\
\hline
\end{tabular}

The levels of concentrations of Compound 1 were undetectable at the first few sampling times (5, 10 and $15 \mathrm{~min})$, and were quantifiable between 30 and $90 \mathrm{~min}$. While, at the same time, it was noted that the transport is slightly higher in the jejunum than the duodenum, compared to the standards (naproxen and amoxicillin), thus it could be considered a molecule with low permeability, as confirmed in the permeability results shown in Table 2 . It should be noted that the $P_{a p p}$ value for clofibrate is $-0.52 \times 10^{-6} \mathrm{~cm} / \mathrm{s}$ ( $\mathrm{pH} 7.4$ ) [33] and is higher than the permeability value for Compound 1 (ATAC) when compared to the value reported for clofibrate. Therefore, it can be deduced that Compound 1 is a molecule able to more easily and quickly permeate than clofibrate, thus improving its potential for absorption.

\subsection{Validation of Analytical Method for Quantifying Compound 1}

\section{Chromatographic Conditions}

The chromatographic system for Compound $\mathbf{1}$ in rat plasma showed the following: a resolution of $3.7(\mathrm{Rs}=3.7)$ between Compound 1 and the internal standard (mebendazol); a resolution of $1.4(\mathrm{Rs}=1.4)$ between Compound $\mathbf{1}$ and the Compound $\mathbf{2}$ (clofibric acid); an asymmetry of 1.2 for Compound 1, 1.3 for the Compound $\mathbf{2}$ and 1.4 for the internal standard; and, a retention time of $13.3 \mathrm{~min}$ for Compound $\mathbf{1}$, 11.9 for the metabolite, and 17.8 for the internal standard. Figure 6 shows a typical chromatogram for Compound $\mathbf{1}$ in rat plasma. The method was selective, in that there was no interference caused by endogenous compounds in the plasma or the products of degradation or impurities.
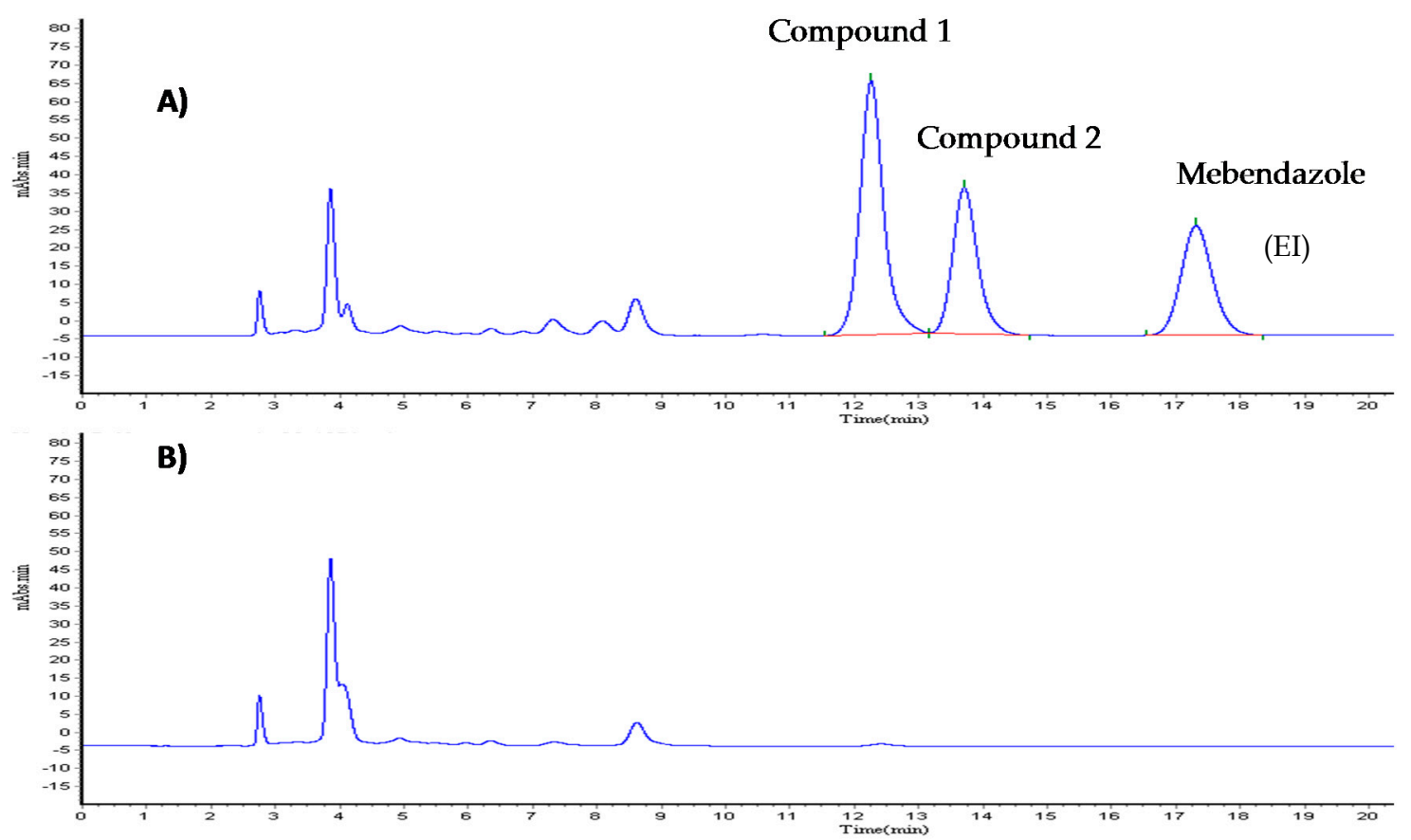

Figure 6. Chromatograms typical of Compound 1 and Compound 2 in rat plasma (A) and black of plasm (B). 
Table 3 shows the parameters of validation obtained for the method used for quantifying Compound 1 . The repeatability results for within-day-one variability present a percentage variation coefficient (RSD\%) lower than 15\%, while the reproducibility results for between-day variability present a RSD\% lower than $15 \%$ in all the levels evaluated. The method used in this study demonstrated an absolute recuperation of over $98.0 \%$ across all levels of control, with the precision of the method ranging from $5.56 \%$ to $13.59 \%$ absolute percentage deviation.

Table 3. Chromatographic parameters and validation results for the quantification method used for both Compound 1 and Compound 2.

\begin{tabular}{ccccccc}
\hline \multirow{2}{*}{ Compound } & \multicolumn{4}{c}{ Validation Parameters } \\
\cline { 2 - 7 } & \multicolumn{3}{c}{ Compound 1 } & \multicolumn{3}{c}{ Compound 2 } \\
\hline Concentration $(\mu \mathrm{g} / \mathrm{mL})$ & $(1.5)$ & $(18)$ & $(24)$ & $(1.5)$ & $(18)$ & $(24)$ \\
Within-day-one variability $(\mathrm{RSD} \%)$ & 5.73 & 14.72 & 5.06 & 8.16 & 3.26 & 1.52 \\
Within-day-two variability (RSD\%) & 13.14 & 2.41 & 7.01 & 8.08 & 2.96 & 5.76 \\
Between-day variability & 10.21 & 10.42 & 6.27 & 7.76 & 7.89 & 4.53 \\
Accuracy (\%) & 13.59 & 7.41 & 5.56 & 6.14 & 8.42 & 12.03 \\
Absolute Recovery & 109.4 & 95.01 & 95.23 & 105.3 & 106.5 & 108.9 \\
\hline
\end{tabular}

The linearity of the method showed a correlation coefficient of over 0.99 in the interval of 0.46 to $30 \mathrm{mg} / \mathrm{mL}$ for Compound 1 and the 0.78 to $50 \mathrm{mg}$ interval $/ \mathrm{mL}$ for the Compound 2. Table 4 shows the confidence intervals for the intercept and slope for both compounds. The limit of quantification was $0.46 \mathrm{mg} / \mathrm{mL}$ both for Compound 1 and Compound 2. The limit detection was $0.30 \mathrm{mg} / \mathrm{mL}$ both Compound 1 and Compound 2.

Table 4. Linearity of quantitation method used for Compound $\mathbf{1}$ and the Compound $\mathbf{2}$ in rat plasma and confidence intervals (CI 95\%) for slope and intercept.

\begin{tabular}{ccccccc}
\hline & \multicolumn{5}{c}{ Linearity } \\
\hline & \multicolumn{7}{c}{ Compound 1 Confidence Intervals $\left(\boldsymbol{\alpha}_{\mathbf{0 . 0 5}}\right)$} & \multicolumn{2}{c}{ Compound 2 Confidence Intervals $\left(\boldsymbol{\alpha}_{\mathbf{0 . 0 5}}\right)$} \\
\cline { 2 - 7 } & Mean Value $(\boldsymbol{n}=\mathbf{4})$ & Lower & Upper & Mean Value $(\boldsymbol{n}=\mathbf{4})$ & Lower & Upper \\
\hline $\mathrm{m}$ & 0.044 & 0.04279 & 0.05027 & 0.0273 & 0.02450 & 0.02903 \\
$\mathrm{~b}$ & -0.0087 & -0.01881 & 0.01626 & -0.0124 & -0.05143 & 0.05516 \\
$\mathrm{r}$ & 0.9997 & & & 0.9989 & & \\
LOQ LOD & $0.46 \mu \mathrm{g} / \mathrm{mL} 0.30$ & & & & & \\
& $\mu \mathrm{gg} / \mathrm{mL}$ & & & & & \\
\hline
\end{tabular}

\section{Bioavailability Evaluation}

Figure 7 presents the pharmacokinetic profiles of Compound 1 after the oral and intravenous administration of a single $50 \mathrm{mg} / \mathrm{kg}$ dose. The non-compartmental analysis is shown in Table 5 .

Figure 7 shows that, in orally administration, Compound 1 presents a $C_{\max }$ of $3.57 \mu \mathrm{g} / \mathrm{mL}$, and that it was only possible to determine its plasmatic concentrations up to one hour after oral administration. Plasmatic concentrations were found up to two hours after intravenous administration. 


\section{Plasma Concentration-time of Compound 1}
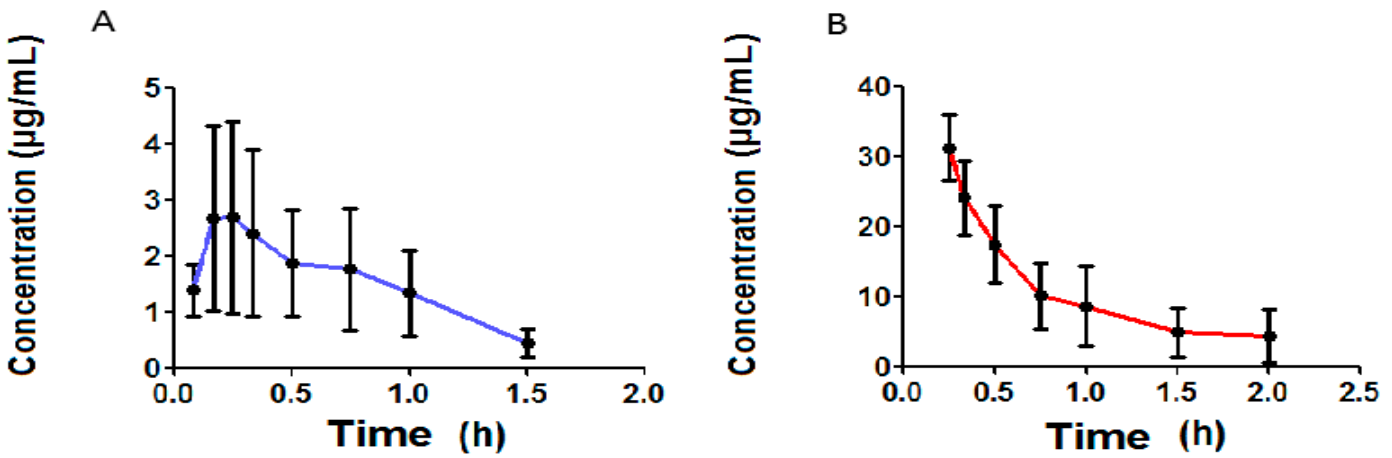

Figure 7. The Compound 1 plasma concentration $\left(\mu \mathrm{g} \cdot \mathrm{mL}^{-1}\right)$ time profile obtained oral administration (A) and intravenous (B) in Wistar rats, mean \pm SE $(n=6)$, respectively.

Table 5. The mean pharmacokinetics parameters for Compound $\mathbf{1 .}$

\begin{tabular}{ccccc}
\hline \multirow{2}{*}{ Parameter } & \multicolumn{2}{c}{ Oral Administration } & \multicolumn{2}{c}{ Intravenous Administration } \\
\cline { 2 - 5 } & Mean & S.D. & Mean & S.D. \\
\hline Kel $\left(\mathrm{h}^{-1}\right)$ & 1.81 & 0.09 & 1.21 & 0.59 \\
$\mathrm{Ka}\left(\mathrm{h}^{-1}\right)$ & 3.05 & 1.07 & & \\
$\mathrm{~T} 1 / 2 \mathrm{el}(\mathrm{h})$ & 0.38 & 0.02 & 0.71 & 0.38 \\
$\mathrm{~T} 1 / 2 \mathrm{abs}(\mathrm{h})$ & 0.25 & 0.09 & & \\
$\mathrm{C}_{\max }(\mu \mathrm{g} / \mathrm{mL})$ & 3.57 & 2.39 & & \\
$\mathrm{~T}_{\max }(\mathrm{h})$ & 0.33 & 0.28 & & \\
$\mathrm{ABC}_{0-\mathrm{t}}(\mu \mathrm{g} / \mathrm{mL} \cdot \mathrm{h})$ & 2.37 & 1.80 & 30.5 & 9.8 \\
$\mathrm{ABC}_{0-\alpha}(\mu \mathrm{g} / \mathrm{mL} \cdot \mathrm{h})$ & 2.58 & 1.97 & 38.8 & \\
$\mathrm{Bioavailability}(\%)_{\mathrm{Cl}(\mathrm{mL} / \mathrm{h})}^{10.4}$ & 751.2 & 0.04 & & 282.2 \\
$\mathrm{Vd}(\mathrm{mL})$ & 419.4 & 148.6 & 484.5 & 93.9 \\
$\mathrm{Vd}(\mathrm{L} / \mathrm{kg})$ & 1.43 & 0.61 & 399.6 & 0.18 \\
Dose $(\mathrm{mg})$ & 15.11 & 1.92 & 15.23 & 1.88 \\
\hline
\end{tabular}

Rapid absorption was observed for the oral administration of Compound 1, presenting a constant average absorption of $3.05 \mathrm{~h}^{-1}$ and an average $C_{\max }$ of $3.57 \mu \mathrm{g} / \mathrm{mL}$ at $0.33 \mathrm{~h}$. The average elimination rate constant for oral administration was $1.81 \mathrm{~h}^{-1}$, while, for intravenous administration this was $1.21 \mathrm{~h}^{-1}$, a difference which was not statistically significant using the $t$-test for unequal variances $(p=0.1410)$. The average distribution volume for oral administration is $419.4 \mathrm{~mL}$, while this was $399.6 \mathrm{~mL}$ for intravenous administration, with neither administration pathways presenting a statistically significant difference $(p=0.8296)$. With the average distribution expressed in $\mathrm{L} / \mathrm{kg}$ due to the fact that it varies along with the animal's body weight, the calculation of the relationship between distribution volume and body weight gives an average distribution volume for oral administration of $1.43 \mathrm{~L} / \mathrm{kg}$ and $1.30 \mathrm{~L} / \mathrm{kg}$ for intravenous administration, indicating a wide distribution of Compound 1 in the rat organism. Rodents (rat) have been reported to present a total blood volume of $64 \mathrm{~mL} / \mathrm{kg}$, giving $3.2 \mathrm{~mL}$ [34] of total blood in a rat weighing approximately $200 \mathrm{~g}$. This data shows that Compound $\mathbf{1}$ is widely distributed in the rat organism. Moreover, distribution volume is a constant parameter for a specific molecule. Compound 1 presents an average clearance (CL) of $751.2 \mathrm{~mL} / \mathrm{min}$ for oral administration and $484.5 \mathrm{~mL} / \mathrm{min}$ for intravenous administration, indicating a wide clearance in the rat organism. The clearance for Compound $\mathbf{1}$ for both administration pathways did not present statistically significant differences $(p=0.2018)$. The bioavailability of Compound 1 was $10.4 \%$, which suggests that the metabolism suffers due to the effect of the first step. The average $\mathrm{ABC}_{0-\alpha}$ for oral administration was $2.58(\mu \mathrm{g} \cdot \mathrm{mL} / \mathrm{h})$, which is lower than the average $\mathrm{ABC}_{0-\alpha}$ recorded for intravenous administration, $38.8(\mu \mathrm{g} \cdot \mathrm{mL} / \mathrm{h})$, indicating that a lower amount of Compound 1 reaches the central 
circulatory system via oral administration. Some pharmacokinetic parameters for fibrates, such as clofibrate, which generates clofibric acid (its active metabolite) with an average lifetime of 7-8 h reported in the rat $[35,36]$ are very different to Compound 1 , which presented an average lifetime of $0.71 \mathrm{~h}$. It is likely that, in the future, Compound 1 could be used as a prodrug, in that it generates a metabolite with an average lifetime of $9 \mathrm{~h}$, which is very similar to that reported for clofibric acid.

Table 6 presents the pharmacokinetic parameters of the Compound 2 (metabolite) (Figure 8) formed by both administration pathways (oral and intravenous). This Compound $\mathbf{2}$ is possibly associated with clofibric acid through the administration of a single $50 \mathrm{mg} / \mathrm{kg}$ dose of Compound $\mathbf{1}$, given that the metabolism of Compound $\mathbf{1}$ is thought to be principally related to enzymatic hydrolysis, as shown in Figure 9.

Table 6. The mean pharmacokinetics parameters for the Compound 2 generated both orally and intravenously.

\begin{tabular}{ccccc}
\hline \multirow{2}{*}{ Parameter } & \multicolumn{2}{c}{ Oral Pathway } & \multicolumn{2}{c}{ Intravenous Pathway } \\
\cline { 2 - 5 } & Mean & S.D. & Mean & S.D. \\
\hline $\mathrm{k}_{\text {elm }}\left(\mathrm{h}^{-1}\right)$ & 0.10 & 0.06 & 0.11 & 0.07 \\
$\mathrm{~T}_{1 / 2 \text { elm }(\mathrm{h})}$ & 9.24 & 5.5 & 9.00 & 5.72 \\
$\mathrm{~T}_{\max }(\mathrm{h})$ & 2 & 0.71 & 0.75 & 0.29 \\
$\mathrm{C}_{\max }(\mu \mathrm{g} / \mathrm{mL})$ & 69.64 & 47.83 & 70.58 & 12.5 \\
$\mathrm{ABC}_{0-\mathrm{t}}(\mu / \mathrm{mL} \cdot \mathrm{h})$ & 340.94 & 135.77 & 386.98 & 243.57 \\
$\mathrm{ABC}_{0-\alpha}(\mu / \mathrm{mL} \cdot \mathrm{h})$ & 956.54 & 661.02 & 747.81 & 185.69 \\
\hline
\end{tabular}

\section{Plasma Concentration-time of Compound 2}

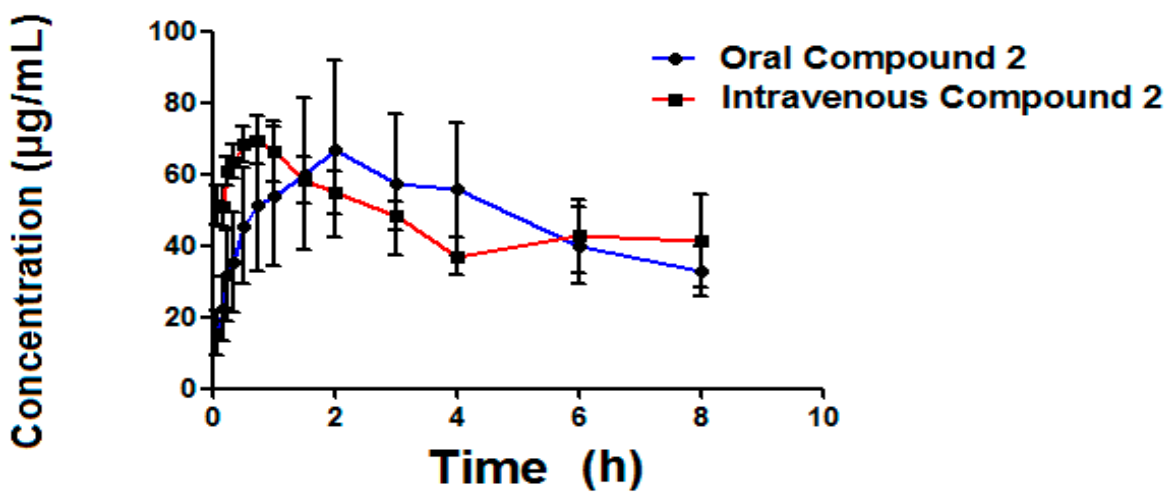

Figure 8. The Compound 2 plasma concentration $\left(\mu \mathrm{g} \cdot \mathrm{mL}^{-1}\right)$ time profile obtained oral and intravenous in Wistar rats, mean $\pm \mathrm{SE}(n=6)$, respectively.

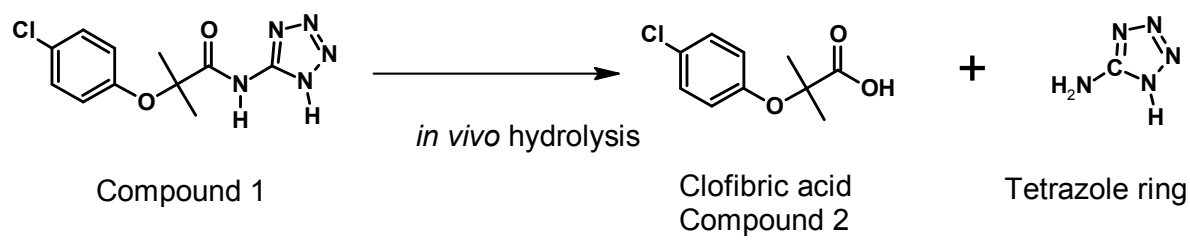

Figure 9. Hydrolysis reaction for Compound 1.

As seen in Figure 9, it was possible to detect, simultaneous to the analysis of Compound 1, the appearance of a Compound 2, which is possibly related to clofibric acid.

Certain parameters of the metabolite were able to be detected (Table 6), such as: $\mathrm{ABC}_{0-\mathrm{t}}, \mathrm{ABC}_{0-\alpha}$, $\mathrm{C}_{\max }$, and $\mathrm{T}_{\max }$. It can be seen that the area below the curve for both metabolites is very similar, 
where, with intravenous administration, it can be seen that the metabolite is generated more quickly than with oral administration, indicating a higher plasmatic metabolism. The $\mathrm{C}_{\max }$ for the metabolite obtained via intravenous administration is slightly higher $(70.58 \mu \mathrm{g} / \mathrm{mL})$ than the $C_{\max }$ obtained via oral administration $(69.64 \mu \mathrm{g} / \mathrm{mL})$, reinforcing the idea that Compound 1 is metabolized by the liver. The Compound 2, as generated via both administration pathways, is capable of maintaining itself in concentrations still quantifiable after more than $8 \mathrm{~h}$ (Figure 8). Table 6 presents the pharmacokinetic parameters obtained for the Compound 2 . The elimination of constant of the Compound $2\left(k_{e l m}\right)$ generated oral pathway is $0.10 \mathrm{~h}^{-1}$ on average, while for generated intravenous recorded an average of $0.11 \mathrm{~h}^{-1}$, results which do not present a statistically significant difference in the $t$-test $(p=0.1143)$. The average elimination of constant of the Compound $2\left(\mathrm{k}_{\text {elm }}\right)$ generated via oral pathway $\left(0.10 \mathrm{~h}^{-1}\right)$ is very similar to that reported for clofibric acid in the rat $\left(0.11 \mathrm{~h}^{-1}\right)$ [36]. The average lifetime for the Compound 2 when generated oral pathway is $9.24 \mathrm{~h}$ and $9.0 \mathrm{~h}$ for the intravenous pathway, results which do not present a statistically significant difference in the $t$-test $(0.1590)$. The average lifetime reported for clofibric acid administered orally in the rat is found to be within the range of 7-8 $\mathrm{h}$ [36], which provides evidence that the Compound 2 originated is likely to be said compound. The average $\mathrm{ABC}_{0-\mathrm{t}}$ for the Compound 2 originating from the oral pathway was $340.94(\mu / \mathrm{mL} \cdot \mathrm{h})$, and $386.98(\mu / \mathrm{mL} \cdot \mathrm{h})$ for the intravenous pathway, results which were not statistically different, according to the T-test $(p=0.7317)$.

\section{Conclusions}

According to the results obtained, Compound $\mathbf{1}$ is a molecule of average polarity, with the non-ionized species formed having a $\mathrm{pH}$ lower than 5 . It presents the behavior of a diacid and has a low permeability. However, its permeability is slightly higher than that shown by amoxicillin, the standard for low permeability. The average lifetime of its absorption was $3.05 \mathrm{~h}$, while the elimination half-life was approximately $0.38 \mathrm{~h}$, presenting a low level of bioavailability, with an average of $10.4 \%$, generating a metabolite that is most likely to be clofibric acid. On appearing, said metabolite is responsible for the therapeutic effect, presenting an average elimination half-life of $9.24 \mathrm{~h}$. This indicates that Compound 1 is a possible prodrug candidate, in that clofibrate is a liquid prodrug that is not very soluble in aqueous media and that generates its active metabolite, clofibric acid, via hydrolysis in vivo. This Compound 2 has a reported $\mathrm{DL}_{50}$ of $940 \mathrm{mg} / \mathrm{kg}$ [37] via oral administration in the rat, while, according to in silico predictions, Compound 1 has a DL 50 of $2200 \mathrm{mg} / \mathrm{kg}$ [17] being a compound with a lower toxicity than clofibrate. It should also be noted that another advantage of Compound $\mathbf{1}$ is that it is a solid powder, making it easier to formulate than clofibrate. One of the disadvantages of Compound $\mathbf{1}$ is that, like clofibrate, it has little aqueous solubility, requiring it to be used in an adequate formulation in order to obtain optimal solubility for Compound $\mathbf{1}$ in aqueous media.

Acknowledgments: This study was taken in part from the $\mathrm{PhD}$ Thesis of Nancy Vara-Gama, and was supported in part by internal funds from the Pharmacy Faculties at the UAEM and Universidad de Guanajuato. Nancy Vara-Gama thanks the Consejo Nacional de Ciencia y Tecnologia (CONACyT, or the National Council for Science and Technology) for the fellowship (Registration No. 228595) awarded during the realization of this study. Likewise, the support given by the Dirección General de Apoyo a la Investigacion y al Posgrado (DAIP, or the General Support Office for Research and Postgraduate Studies) at the Universidad de Guanajuato for the revision of the manuscript in English is appreciated. Thanks also to the program for professional teacher development, for the higher type (PRODEP).

Author Contributions: Nancy Vara-Gama is the principal researcher, who designed and developed the studies as part of the doctoral project. Adriana Valladares-Méndez contributes with the work in the studies, animal handling and technical support in the different analytical methodologies. Gabriel Navarrete-Vázquez developed the synthesis of Compound 1 and performs the evaluation of physicochemical characterization. Samuel Estrada-Soto advised on the design of pharmacological studies. Luis Orozco-Castellanos supervised the development of formulations for oral and intravenous administration, coordinated the activities of physicochemical tests and general activities of the doctoral thesis project. Julio César Rivera-Leyva designed the general structure of the study, designed the pharmacokinetic studies and coordinated the general activities of the doctoral thesis project.

Conflicts of Interest: The authors declare that no conflict of interest exists. 


\section{References}

1. Mbanya, J.C. Plan Mundial Contra la Diabetes 2011-2021; International Diabetes Federation: Bruselas, Bélgica, 2011; pp. 1-27.

2. Instituto Nacional de Salud Pública. Encuesta Nacional de Salud y Nutrición 2012. Resultados Nacionales, 1st ed.; Secretaría de Salud: Cuernavaca, CUE, Mexico, 2012; pp. 1-200.

3. Cefalu, W.T. Standards of medical care in diabetes-2016. Am. Diabetes Assoc. 2016, 39, S4-S5.

4. Defronzo, R.A.; Eldor, R.; Abdul-Ghani, M. Pathophysiologic approach to therapy in patients with newly diagnosed type 2 diabetes. Diabetes Care 2013, 36, 127-238. [CrossRef] [PubMed]

5. Torres-Arreola, L.; Gil-Velázquez, L.E.; Sil-Acosta, M.J.; Domínguez-Sánchez, E.R.; Parrilla-Ortiz, J.I.; Santillana-Hernández, S. Guía de practica clinica GPC diabetes mellitus tipo 2 en el primer nivel de atención evidencias y recomendaciones catalogo maestro de guias de practica clinica: IMSS-718-14 tratamiento de la diabetes mellitus tipo 2 en el primer nivel de atención. Inst. Mex. del Seguro Soc. 2014, 1, 1-136.

6. Gil-Vazquez, L.E.; Sil-Acosta, M.J.; Dominguez-Sanchez, E.R.; del Torres-Arreola, L.; Medina-Chavez, J.H. Guia de practica clinica. Diagnóstico y tratamiento de la diabetes mellitus tipo 2. Rev. Med. Inst. Mex. Seguro Soc. 2013, 51, 1-16.

7. Ros, E.; Laguna, J.C. Treatment of hypertriglyceridemia: Fibrates versus omega-3 fatty acids. Rev. Española Cardiol. 2006, 6, 52-61. [CrossRef]

8. Hormigo-Pozo, A.; Mancera-Romero, J.; Perez-Unanua, M.P.; Alonso-Fernandez, M.; Lopez-Simarro, F.; Mediavilla-Bravo, J.J. Recomendaciones de buena practica en el tratamiento de la dislipemia en la diabetes. Semergen 2015, 41, 89-98. [CrossRef] [PubMed]

9. Tachibana, K.; Anzai, N.; Ueda, C.; Katayama, T.; Kirino, T.; Takahashi, R.; Yamasaki, D.; Ishimoto, K.; Tanaka, T.; Hamakubo, T.; et al. Analysis of PPAR alpha function in human kidney cell line using siRNA. Nucleic Acids Symp. Ser. 2006, 50, 257-258. [CrossRef] [PubMed]

10. Litherland, N.B.; Bionaz, M.; Wallace, R.L.; Loor, J.J.; Drackley, J.K. Effects of the peroxisome proliferator-activated receptor- $\alpha$ agonists clofibrate and fish oil on hepatic fatty acid metabolism in weaned dairy calves 1. J. Dairy Sci. 2010, 93, 2404-2418. [CrossRef] [PubMed]

11. Kim, C.H.; Ramu, R.; Ahn, J.H.; Bae, M.A.; Cho, Y.S. Fenofibrate but not fenofibric acid inhibits 11betahydroxysteroid dehydrogenase 1 in $\mathrm{C}_{2} \mathrm{C}_{12}$ myotubes. Mol. Cell Biochem. 2010, 344, 91-98. [CrossRef] [PubMed]

12. Alberts, P.1.; Engblom, L.; Edling, N.; Forsgren, M.; Klingström, G.; Larsson, C.; Rönquist-Nii, Y.; Ohman, B.; Abrahmsén, L. Selective inhibition of $11 \beta$-hydroxysteroid dehydrogenase type 1 decreases blood glucose concentrations in hyperglycaemic mice. Diabetologia 2002, 45, 1528-1532. [PubMed]

13. Anderson, A.; Walker, B.R. 11 $\beta$-HSD1 inhibitors for the treatment of type 2 diabetes and cardiovascular disease. Drugs 2013, 73, 1385-1393. [CrossRef] [PubMed]

14. Shetty, S.R.; Kumar, S.; Mathur, R.P.; Sharma, K.H.; Jaiswal, A.D. Observational study to evaluate the safety and efficacy of saroglitazar in Indian diabetic dyslipidemia patients. Indian Heart J. 2015, 67, 23-26. [CrossRef] [PubMed]

15. He, B.K.; Ning, Z.Q.; Li, Z.B.; Shan, S.; Pan, D.S.; Ko, B.C.; Li, P.P.; Shen, Z.F.; Dou, G.F.; Zhang, B.L.; et al. In vitro and in vivo characterizations of chiglitazar, a newly identified PPAR pan-agonist. PPAR Res. 2012, 2012, 546548. [CrossRef] [PubMed]

16. Ballatore, C.; Huryn, D.M.; Smith, A.B. Carboxylic Acid (Bio)Isosteres in Drug Design. ChemMedChem 2013, 8, 385-395. [CrossRef] [PubMed]

17. Alaniz-Palacios, A. Diseño, Sintesis y Caracterización Mediante Difracción de Rayos-X de amidas Azaheterociclicas Derivadas del Acido Clofibrico Como Inhibidores de la Enzima 11ß-HSD1, Bachelor; Facultad de Farmacia, Universidad Autónoma del Estado de Morelos: Cuernavaca, Morelos, Mexico, 2011.

18. Navarrete-Vázquez, G.; Alaniz-Palacios, A.; Hidalgo-Figueroa, S.; González-Acevedo, C.; Ávila-Villarreal, G.; Estrada-Soto, S.; Webster, S.P.; Medina-Franco, J.L.; López-Vallejo, F.; Guerrero-Álvarez, J.; et al. Discovery, synthesis and in combo studies of a tetrazole analog of clofibric acid as a potent hypoglycemic agent. Bioorg. Med. Chem. Lett. 2013, 23, 3244-3247. [CrossRef] [PubMed]

19. Ramírez-Espinosa, J.J.; García-Jiménez, S.; Rios, M.Y.; Medina-Franco, J.L.; López-Vallejo, F.; Webster, S.P.; Binnie, M.; Ibarra-Barajas, M.; Ortiz-Andrade, R.; Estrada-Soto, S. Antihyperglycemic and sub-chronic antidiabetic actions of morolic and moronic acids, in vitro and in silico inhibition of 11ß-HSD 1. Phytomedicine 2013, 20, 571-576. [CrossRef] [PubMed] 
20. Babić, S.; Horvat, A.J.M.; Mutavdžić Pavlović, D.; Kaštelan-Macan, M. Determination of pKa values of active pharmaceutical ingredients. Trends Anal. Chem. 2007, 26, 1043-1061. [CrossRef]

21. Clarlk College. Potentiometric Titrationofa Weak Acid. Chemistry. Available online: http://web.clark.edu/ nfattaleh/classes/135/Sp05/Labs/PotTitrSp05.pdf (accessed on 9 february 2017).

22. Scott, D.C.; Clymer, C.J. Stimation of distribution coefficients from the partition coefficient and $\mathrm{pKa}$. Pharm. Tecnol. 2002, 26, 30-40.

23. Shawahna, R.; Rahman, N.U. Evaluation of the use of partition coefficients and molecular surface properties as predictors of drug absorption: A provisional biopharmaceutical classification of the list of national essential medicines of Pakistan. DARU 2011, 19, 83-98. [PubMed]

24. Takacs-Novak, K.; Avdeef, A. Interlaboratory study of log P determination by shake-flask and potentiometric methods. J. Pharm. Biomed. Anal. 1996, 14, 1405-1413. [CrossRef]

25. Krimsky, M.; Dagan, A.; Aptekar, L.; Ligumsky, M.; Yedgar, S. Assessment of intestinal permeability in rats by permeation of inulin-fluorescein. J. Basic Clin. Physiol. Pharmacol. 2000, 11, 143-153. [CrossRef] [PubMed]

26. Ashimura, J.K.; Agai, Y.N. Inhibitory effect of palatinose on glucose absorption in everted rat gut. J. Nutr. Sci. Vitaminol. 2007, 53, 87-89. [CrossRef]

27. Secretaria de Salud. Norma Oficial Mexicana NOM-177-SSA1-2013, Que Establece las Pruebas y Procedimientos Para Demostrar que un Medicamento es Intercambiable. Requisitos a que Deben Sujetarse los Terceros Autorizados queRealicenlasPruebasdeIntercambiabilidad. Available online: http:/ /www.dof. gob.mx/nota_detalle.php?codigo=5314833\&fecha=20/09/2013 (accessed on 9 February 2017).

28. Balla, D.Z.; Schwarz, S.; Wiesner, H.M.; Hennige, A.M.; Pohmann, R. Monitoring the stress-level of rats with different types of anesthesia: A tail-artery cannulation protocol. J. Pharmacol. Toxicol. Methods 2014, 70, 35-39. [CrossRef] [PubMed]

29. Rowland, M.; Tozer, T.N.; Derendorf, H.; Hochhaus, G. Clinical Pharmacokinetics and Pharmacodynamics Concepts and Applications, 4th ed.; Lippincott Williams \& Wilkins: Philadelphia, PA, USA, 2011; pp. 1-20.

30. Doménech, B.J.; Martínez-Lanao, J.; Plá Delfina, J.M. Biofarmacia y Farmacocinética, 1st ed.; Síntesis, S.A., Ed.; Universidad Autónoma de Madrid: Madrid, Spain, 2001; Volume 1, pp. 322-420.

31. Nordisk, N. Directive 2010/63/EU on Protection of Animals Used for Scientific Purposes, Caring for Animals Aiming for Better Science. Off. J. Eur. Union. 2010, 1-158.

32. Secretaria de Agricultura, Ganaderia, Desarrollo Rural, Pesca y Alimentación. Norma Oficial Mexicana NOM-062-ZOO-1999, Especificaciones Técnicas Para la Producción, Cuidado y uso de los Animales de Laboratorio. Available online: http://www.ibt.unam.mx/computo/pdfs/bioterio.NOM-062.pdf (accessed on 9 february 2017).

33. Karelson, M.; Karelson, G.; Tamm, T.; Tulp, I.; Jänes, J.; Tämm, K.; Lomaka, A.; Savchenko, D.; Dobchev, D. QSAR study of pharmacological permeabilities. Arkivoc 2009, 2, 218-238.

34. Diehl, K.H.; Hull, R.; Morton, D.; Pfister, R.; Rabemampianina, Y.; Smith, D.; Vidal, J.M.; van de Vorstenbosch, C.; European Federation of Pharmaceutical Industries Association and European Centre for the Validation of Alternative Methods. A good practice guide to the administration of substances and removal of blood, including routes and volumes. J. Appl. Toxicol. 2001, 21, 15-23. [CrossRef] [PubMed]

35. Elmore, C.L. Center for Drugs Evaluation and Research. In Pharmacology/Toxycology and Evaluation; Departament of Health and Human Services Public Health Service Food and Drug Administration: Philadelphia, PA, USA, 2009; pp. 1-74.

36. Crouthamel, W.G.; Cenedella, R.J. Clofibrate pharmacokinetics: Effect of elevation of plasma-free fatty acids. Pharmacology 1975, 13, 465-473. [CrossRef] [PubMed]

37. Drugbank. Drugcard of Clofibrate. Available online: http://www.drugbank.ca/drugs/DB00636 (accessed on 9 February 2017).

Sample Availability: Sample of the compound $\mathbf{1}$ is available from the authors.

(C) 2017 by the authors; licensee MDPI, Basel, Switzerland. This article is an open access article distributed under the terms and conditions of the Creative Commons Attribution (CC BY) license (http://creativecommons.org/licenses/by/4.0/). 